February 2005 - NREL/CP-520-37379

\title{
Status of High Performance PV: Polycrystalline Thin-Film Tandems
}

M. Symko-Davies

Prepared for the $31^{\text {st }}$ IEEE Photovoltaics Specialists Conference and Exhibition

Lake Buena Vista, Florida

January 3-7, 2005

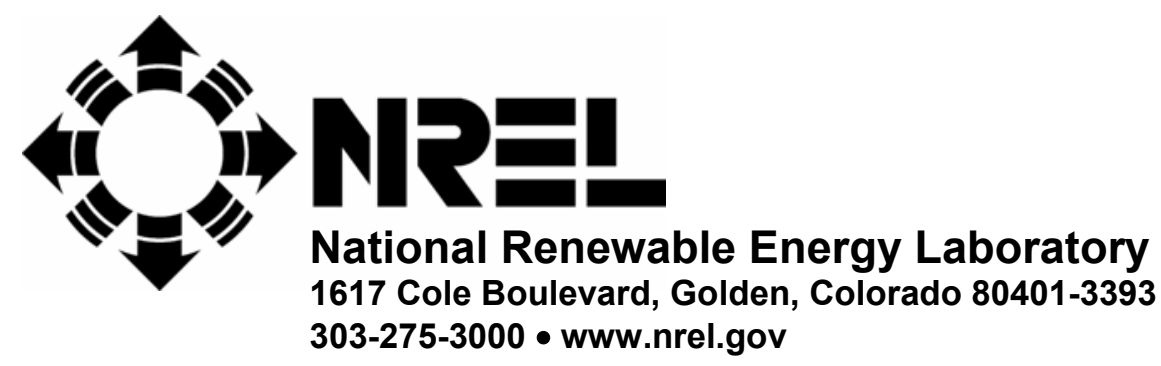

Operated for the U.S. Department of Energy

Office of Energy Efficiency and Renewable Energy

by Midwest Research Institute $\bullet$ Battelle

Contract No. DE-AC36-99-G010337 


\section{NOTICE}

The submitted manuscript has been offered by an employee of the Midwest Research Institute (MRI), a contractor of the US Government under Contract No. DE-AC36-99G010337. Accordingly, the US Government and MRI retain a nonexclusive royalty-free license to publish or reproduce the published form of this contribution, or allow others to do so, for US Government purposes.

This report was prepared as an account of work sponsored by an agency of the United States government. Neither the United States government nor any agency thereof, nor any of their employees, makes any warranty, express or implied, or assumes any legal liability or responsibility for the accuracy, completeness, or usefulness of any information, apparatus, product, or process disclosed, or represents that its use would not infringe privately owned rights. Reference herein to any specific commercial product, process, or service by trade name, trademark, manufacturer, or otherwise does not necessarily constitute or imply its endorsement, recommendation, or favoring by the United States government or any agency thereof. The views and opinions of authors expressed herein do not necessarily state or reflect those of the United States government or any agency thereof.

Available electronically at http://www.osti.gov/bridge

Available for a processing fee to U.S. Department of Energy and its contractors, in paper, from:

U.S. Department of Energy

Office of Scientific and Technical Information

P.O. Box 62

Oak Ridge, TN 37831-0062

phone: 865.576 .8401

fax: 865.576.5728

email: mailto:reports@adonis.osti.gov

Available for sale to the public, in paper, from:

U.S. Department of Commerce

National Technical Information Service

5285 Port Royal Road

Springfield, VA 22161

phone: 800.553 .6847

fax: 703.605.6900

email: orders@ntis.fedworld.gov

online ordering: http://www.ntis.gov/ordering.htm 


\title{
STATUS OF HIGH PERFORMANCE PV: POLYCRYSTALLINE THIN-FILM TANDEMS
}

\author{
Martha Symko-Davies \\ National Renewable Energy Laboratory (NREL), Golden, CO
}

\begin{abstract}
The High-Performance Photovoltaic (HiPerf PV) Project was initiated by the U.S. Department of Energy to substantially increase the viability of photovoltaics (PV) for cost-competitive applications so that PV can contribute significantly to our energy supply and our environment. The HiPerf PV Project aims at exploring the ultimate performance limits of existing PV technologies, approximately doubling their sunlight-to-electricity conversion efficiencies during its course. This work includes bringing thin-film cells and modules toward $25 \%$ and $20 \%$ efficiencies, respectively; and developing multijunction concentrator cells and modules able to convert more than one-third of the sun's energy to electricity (i.e., 33\% efficiency). This paper will address recent accomplishments of the NREL in-house research effort involving polycrystalline thin-film tandems, as well as the research efforts under way in the subcontracted area.
\end{abstract}

\section{INTRODUCTION}

The HiPerf PV Project directs Federal resources toward some of the most critical barriers to the widespread use of photovoltaics for energy-significant applications. This addresses one of the highest-priority goals for applied research in the U.S. Photovoltaics Industry Roadmap [1]: "developing high-efficiency, low-cost materials and devices."

This paper will describe progress on exploring critical pathways for a PV technology having a high potential to reach cost-competitiveness goals: low-cost polycrystalline thin-film tandems for large-area, flat-plate modules. The concept was introduced to increase efficiency, but its potential for reducing cost also became apparent many years ago [2].

This technology has the potential to reach the installed system cost goal of about $\$ 1 / \mathrm{Wp}$ with continued progress in efficiency, reliability, and manufacturing cost.

\section{PROJECT GOALS AND OBJECTIVES}

The NCPV at NREL directs in-house and subcontracted research in high-performance polycrystalline thin-film and multijunction concentrator devices. During the project period, extensive collaboration and the work performed to push the research toward established goals should produce significant contributions to the entire PV industry. A roadmap of the High-Performance PV Project approach is shown covering approximately the next decade (Fig. 1).

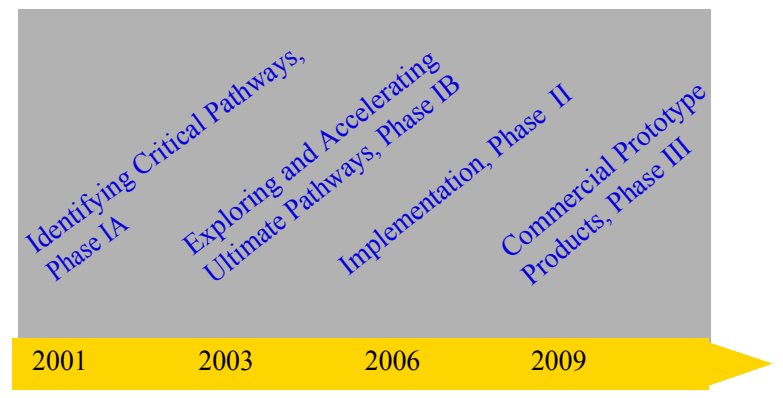

Fig. 1. Roadmap of the High-Performance PV Project.

The first phase of the project is critical, because it provides a means to identify, explore, and accelerate the most promising paths for implementation, followed by commercial prototype products. These latter efforts constitute the second and third phases of this planned research program. The first of a two-part phase, "Identifying Critical Pathways," investigated a wide range of complex issues in both the polycrystalline thin-film tandems and III-V multijunctions for the longer-term development and application of high-performance PV technologies. The current Phase IB, "High-Performance PV-Exploring and Accelerating Ultimate Pathways," is a continuation of Phase I and addresses exploring and accelerating ultimate pathways to reach the project's longterm goals. It is thought that several promising approaches will be explored in each category during this phase, which will lead to Phase II, "Implementation of Pathways." Seven companies and universities were competitively selected and have received awards for the HiPerf PV Phase IB (see Table 1).

\begin{tabular}{|l|l|}
\hline Subcontractor & Title \\
\hline $\begin{array}{l}\text { Georgia Institute of } \\
\text { Technology }\end{array}$ & $\begin{array}{l}\text { Thin-Film Si Bottom } \\
\text { Cells for Tandem Device } \\
\text { Structures }\end{array}$ \\
\hline $\begin{array}{l}\text { University of Delaware } \\
\text { (IEC) }\end{array}$ & $\begin{array}{l}\text { High-Performance PV- } \\
\text { Polycrystalline Thin-Film } \\
\text { tandem Cells }\end{array}$ \\
\hline
\end{tabular}




\begin{tabular}{|l|l|}
\hline University of Toledo & $\begin{array}{l}\text { Sputtered II-VI Alloys and } \\
\text { Structures for Tandem PV }\end{array}$ \\
\hline University of Florida & $\begin{array}{l}\text { Identification of Critical } \\
\text { Paths in the } \\
\text { Manufacturing of Low- } \\
\text { Cost High-Efficiency } \\
\text { CGS/CIS Two-Junction } \\
\text { Tandem Cells }\end{array}$ \\
\hline University of Oregon & $\begin{array}{l}\text { Identifying the Electronic } \\
\text { Properties Relevant to } \\
\text { Improving the Performance of } \\
\text { High-Bandgap Copper-Based } \\
\text { I-III-VI } \\
\text { PV Devalcopyrite Thin-Film }\end{array}$ \\
\hline Oregon State & $\begin{array}{l}\text { Novel Materials Development } \\
\text { for Polycrystalline Thin-Film } \\
\text { Solar Cells }\end{array}$ \\
\hline Light Spin & $\begin{array}{l}\text { Novel Polycrystalline Thin- } \\
\text { Film Solar Cells }\end{array}$ \\
\hline
\end{tabular}

Table 1. Phase IB, "Exploring and Accelerating Ultimate Pathways" Subcontractor Awards

\section{PROJECT GOALS AND R\&D FOCUS}

\section{Goals}

To address HiPerf PV R\&D long-term goals of bringing polycrystalline thin-film tandem cells (combining high-bandgap and low-bandgap single junctions) and modules toward $25 \%$ and $20 \%$ efficiencies, respectively, the project investigates a wide range of complex issues and provides initial modeling and baseline experiments of several advanced concepts. Recent work by Coutts et al. [3] modeling state-of-the-art thin-film devices has provided critical guidance for the project. A near-term milestone chart of the R\&D thin-film polycrystalline tandems is shown by year and will be described here (see Table 2). Throughout the project's term, there will be opportunities to reach established program goals by both disruptive technology advances and/or multiple incremental improvements.

\begin{tabular}{|c|c|}
\hline Date & Milestone \\
\hline 2002 & $\begin{array}{l}\text { 10\%-Efficient, } 1.5<\text { Egap }<1.8 \text { eV Cell } \\
\text { (Completed) }\end{array}$ \\
\hline 2003 & $\begin{array}{l}\text { Compare Device Design in Terms of } \\
\text { Monolithic/Mechanical Structure } \\
\text { (Completed) }\end{array}$ \\
\hline 2004 & $\begin{array}{l}\text { Assess Research on Exploring } \\
\text { Pathways }\end{array}$ \\
\hline 2005 & $\begin{array}{l}\text { 14\%-Efficient Polycrystalline Thin- } \\
\text { Film Tandem }\end{array}$ \\
\hline 2006 & $\begin{array}{l}\text { 15\%-Efficient PolycrystallineThin-Film } \\
\text { Tandem }\end{array}$ \\
\hline
\end{tabular}

Table 2. Near-term Milestones, High-Performance PV Project, Polycrystalline Thin-Film Tandems.

\section{R\&D Focus and Advancements}

The wide-bandgap top cell material of the tandem is critical; it is anticipated that two-thirds of the tandem cell efficiency originates here. Therefore, R\&D is focused on a top cell, which is integrated with the bottom cell via an interconnect junction. Transmission through the top cell is a challenge, requiring an optical bandgap $\left(E_{g}\right)$ in the range of $1.5<\mathrm{E}_{\mathrm{g}}<1.8 \mathrm{eV}$ and minimal sub-bandgap absorption. Process compatability to maintain the performance of the bottom cell is essential.

Integration of the thin-film interconnect with the top cell-optically, electrically, and with an eye toward process compatibility is being investigated; this includes the role of defects and how they affect the transport properties of this junction, as well as diffusion of impurities into the bulk. Transparent conducting oxides (TCOs) are able to form a one-sided $\mathrm{p} / \mathrm{n}+$ interconnect (shorting/tunneling junction) between the TCO and a non-degenerate p-type absorber [4], playing a strong role in the tandem cell.

The design in terms of a monolithic or mechanical stack is primarily determined by the choice of the highbandgap top cell material. There are pros and cons to both approaches. For example, with the monolithic approach, only one thick TCO, one grid, and one anti-reflection coating (ARC) would be needed. However, currentmatching and temperature-stability issues arise, as well as the necessity of a close thickness tolerance with the tunnel junction. Whereas the mechanical stack design may appear at first glance much simpler than the monolithic design, other issues are involved. For example, more materials (ARCs, TCOs, and glass) would be needed for the overall structure. Regardless of the designs, both structures are being pursued during the project.

\section{HIGH-BANDGAP MATERIALS}

Several high-bandgap top cell materials have been identified under the project, but they still need further exploration (see Table 3 ). The table lists several materials that have been highly successful in terms of the operating parameters for the tandem structure.

The Polycrystalline Thin Film PV Group at NREL has demonstrated that a surface-modified CGS cell exhibits the following NREL-confirmed device operating parameters: $\mathrm{V}_{\mathrm{oc}}=0.823$ volts, $\mathrm{J}_{\mathrm{sc}}=18.61 \mathrm{~mA} / \mathrm{cm}^{2}$, fill factor $=66.8 \%$, and total-area efficiency $=10.2 \%$. CGS is a candidate top cell absorber material. Its bandgap is ideal at $1.68 \mathrm{eV}$. This particular device had a bandgap of 1.64 eV. Improving CGS device efficiency has proven to be a challenge over the past several years. The recent understanding of the differences in structural and electronic properties between $\operatorname{Culn}(\mathrm{Ga}) \mathrm{Se}_{2}$ and CGS thin films and devices has led to varying the growth process in a way that is likely to make the CGS surface region similar to that of $\mathrm{Cl}(\mathrm{G}) \mathrm{S}$ and to minimize defects in the material.

The University of Delaware, Institute of Energy Conversion (IEC), is investigating $\mathrm{Cu}(\operatorname{InGa})(\mathrm{SeS})_{2}$ films and $\mathrm{Cd}_{1-\mathrm{x}} \mathrm{Zn} \mathrm{x}$ Te films of varying compositions and on specific substrates for the top cell of the tandem [5]. Solar cells were fabricated at IEC using the structure glass/ $\mathrm{Mo} / \mathrm{Cu}(\operatorname{InGa})(\mathrm{SeS})_{2} / \mathrm{CdS} / \mathrm{ZnO} / \mathrm{ITO}$ with $\mathrm{Ni}-\mathrm{Al}$ collection 
grids and total area, defined by mechanical scribes, of $0.47-0.51 \mathrm{~cm}^{2}$. Current-voltage measurements were completed at NREL on devices from two different depositions. The best cell from one run had efficiency = $10.9 \%$ with $\mathrm{V}_{\mathrm{OC}}=0.826 \mathrm{~V}, \mathrm{~J}_{\mathrm{SC}}=20.4 \mathrm{~mA} / \mathrm{cm}^{2}$, and fill factor $=64.5$. From the other run, the best cell had efficiency $=10.9 \%$ with $\mathrm{V}_{\mathrm{OC}}=0.836 \mathrm{~V}, \mathrm{~J}_{\mathrm{SC}}=20.4 \mathrm{~mA} / \mathrm{cm}^{2}$, and fill factor $=64$. Understanding the growth mechanisms of $\mathrm{Cu}(\operatorname{lnGa})(\mathrm{SeS})_{2}$ films, particularly the incorporation of the chalcogen ( $\mathrm{S}, \mathrm{Se}$ ) species, is fundamental to their application in wide-bandgap solar cells. Using deposition conditions that yield uniform through-film $\mathrm{Cu}(\mathrm{InGa}) \mathrm{Se}_{2}$ composition and high-efficiency devices, the growth of $\mathrm{Cu}(\operatorname{lnGa})(\mathrm{SeS})_{2}$ or Culn(SeS $)_{2}$ has been shown to form a bi-layer film comprising two different chalcopyrite compositions. A layer at the back of the film is relatively rich in $\mathrm{S}$, and a layer near the surface is S-poor relative to the flux during growth. This results in poor device behavior for the mixed chalcogen $(\mathrm{S}+\mathrm{Se})$ films. Although the growth mechanisms that produce this behavior are still under study, this phenomenon appears to be limited by growth kinetics rather than fundamental thermodynamics.

Oregon State has worked on several new compositions, and films are being developed for use as conductive windows, tunnel junctions, and absorbers in tandem solar cells. The material BaCuTeF has been identified as a new p-type semiconductor with a bandgap of $2.3 \mathrm{eV}$.
Measurements on pressed pellets reveal an electrical conductivity of $8 \mathrm{~S} / \mathrm{cm}$ and a Seebeck coefficient of +25 $\mu \mathrm{V} / \mathrm{K}$; the temperature dependence of the electrical conductivity is consistent with degenerate behavior. Thin films of the material are being processed via pulsed laser deposition; these films should interface well with $\mathrm{CdTe}$. In the family of compounds $\mathrm{MCuSnQ}_{4}(\mathrm{M}=\mathrm{Ba}, \mathrm{Sr} ; \mathrm{Q}=\mathrm{S}, \mathrm{Se})$, compositions have been systematically varied to identify the material BaCuSnSe $\mathrm{S}_{2}$ (direct $\mathrm{E}_{\mathrm{g}}=1.77 \mathrm{eV}$ ) as a candidate absorber for top cell applications

\section{PROGRESS IN TANDEM SOLAR CELLS}

Several polycrystalline thin-film tandem designs have been developed and demonstrated under the HiPerf project, but they still need further exploration. Table 4 lists several of these structures, which include both mechanical and monolithic designs, in terms of the operating parameters. Several of these novel devices will be described below.

Researchers at the Georgia Institute of Technology are looking to make Si-based tandem cells compatible to the processing conditions required to fabricate CulnSe ${ }_{2}-$ based solar cells using conventional crystalline $\mathrm{Si}$ cell structures. They have shown that $\mathrm{c}-\mathrm{Si}$ devices remain intact after exposure to $\mathrm{Cu}(\ln \mathrm{Ga}) \mathrm{Se}_{2}$ growth. However, Ag diffusion from the metallization of the $\mathrm{Si}$ cell was observed on the $\mathrm{Cu}(\operatorname{lnGa}) \mathrm{Se}_{2}$ surface. This increased the resistance of the $\mathrm{Si}$ cell and reduced its fill factor.

\begin{tabular}{|c|c|c|c|c|c|c|}
\hline $\begin{array}{l}\text { Organiza } \\
\text { tion }\end{array}$ & $\begin{array}{l}\text { High Band-Gap Top Cell } \\
\text { Structure }(\mathrm{eV})\end{array}$ & $\begin{array}{l}\text { Voc } \\
\text { (V) }\end{array}$ & $\begin{array}{l}\mathrm{Jsc} \\
\left(\mathrm{mA} / \mathrm{cm}^{2}\right)\end{array}$ & $\begin{array}{l}\text { Fill Factor } \\
(\%)\end{array}$ & $\begin{array}{l}\text { Efficiency } \\
\text { (\%) }\end{array}$ & Comments \\
\hline NREL & $\begin{array}{l}\text { Glass/Mo/CGS/CdS/ZnO } \\
(1.64 \mathrm{eV})\end{array}$ & .823 & 18.61 & 66.8 & 10.2 & Surface modified CGS \\
\hline NREL & $\begin{array}{l}\text { Glass/Mo/CGS/CdS/ZnO } \\
(1.68 \mathrm{eV})\end{array}$ & .905 & 14.8 & 70.9 & 9.53 & \\
\hline NREL & $\begin{array}{l}\text { Glass/SnO } / \text { CGS/CdS/ } \\
\mathrm{ZnO}(1.68 \mathrm{eV})\end{array}$ & .864 & 15.36 & 51.25 & 6.8 & $60 \%-70 \%$ transmission \\
\hline $\begin{array}{l}\text { Universit } \\
\text { y of } \\
\text { Delawar } \\
\text { e (IEC) }\end{array}$ & $\begin{array}{l}\text { Glass/Mo/Cu(InGa)Se, } / \mathrm{CdS} / \\
\mathrm{ZnO} / \mathrm{ITO}(1.5 \mathrm{eV})\end{array}$ & .826 & 20.4 & 64.5 & 10.9 & \\
\hline NREL & $\begin{array}{l}\text { Glass } / \mathrm{Cd}_{2} \mathrm{SnO}_{4} / \mathrm{ZnSnO}_{\mathrm{x}} / \mathrm{nan} \\
\mathrm{o}-\mathrm{CdS}: \mathrm{O} / \mathrm{CdTe} / \mathrm{Cu}_{\mathrm{x}} \mathrm{Te}(1.5 \\
\mathrm{eV})\end{array}$ & .806 & 24.97 & 69.22 & 13.9 & $60 \%-40 \%$ transmission \\
\hline
\end{tabular}

Table 3. High-Bandgap Top Cell Structures and their Operating Parameters (NREL verified). 


\begin{tabular}{|c|c|c|c|c|c|c|}
\hline Organization & Tandem Structure & $\operatorname{Voc}(V)$ & $\begin{array}{l}\text { Jsc } \\
\left(\mathrm{mA} / \mathrm{cm}^{2}\right)\end{array}$ & $\begin{array}{l}\text { Fill } \\
\text { Factor } \\
\text { (\%) }\end{array}$ & $\begin{array}{l}\text { Efficiency } \\
\text { (\%) }\end{array}$ & Comment \\
\hline NREL & $\begin{array}{l}\frac{\text { Top cell: glass } / \mathrm{SnO}}{2} 2 \frac{\mathrm{CGS} / \mathrm{CdS} / \mathrm{ZnO}}{\text { Bottom cell: glass } / \mathrm{Mo} / \mathrm{CIS} / \mathrm{CdS} / \mathrm{ZnO}} \\
\underline{\text { Mechanical stack }}\end{array}$ & $\frac{.864}{.456}$ & $\frac{15.36}{12.46}$ & $\underline{51.25}$ & $\frac{\underline{6.8}}{\underline{3.9}}$ & $\begin{array}{l}\text { 4- } \\
\text { terminal } \\
\text { device }\end{array}$ \\
\hline NREL & $\begin{array}{l}\text { Topcell:Glass } / \mathrm{Cd}_{2} \mathrm{SnO}_{4} / \mathrm{ZnSnO} \mathrm{x}_{\mathrm{x}} / \text { nano- } \\
\mathrm{CdS}: \mathrm{O} / \mathrm{CdTe} / \mathrm{Cu}_{\mathrm{x}} \mathrm{Te} \\
\text { Bottom cell: glass/Mo/CIS/CdS/ZnO } \\
\text { Mechanical stack }\end{array}$ & $\begin{array}{l}.786 \\
. .357 \\
\underline{1.14}\end{array}$ & $\begin{array}{l}\underline{25.5} \\
\underline{6.059}\end{array}$ & $\begin{array}{l}\underline{68.9} \\
\underline{68.01}\end{array}$ & $\begin{array}{l}\underline{13.8} \\
\frac{1.47}{15.3} \\
\underline{\underline{15}}\end{array}$ & $\begin{array}{l}\text { 4- } \\
\text { terminal } \\
\text { device }\end{array}$ \\
\hline $\begin{array}{l}\text { University } \\
\text { of Delaware } \\
\text { (IEC) }\end{array}$ & $\begin{array}{l}\text { Monolithic structure: } \\
\text { ZnO/ITO/CdS/ Cu(InGa)Se } \\
\text { /ZnO/CdS/CIS/Mo/glass }\end{array}$ & .688 & 10.4 & 52.8 & 3.8 & \\
\hline $\begin{array}{l}\text { University } \\
\text { of Toledo }\end{array}$ & $\begin{array}{l}\text { Monolithic structure: } \\
\mathrm{SnO}_{2}: \mathrm{F} / \mathrm{CdS} / \mathrm{CdTe} / \mathrm{ZnTe} \mathrm{N} / \mathrm{ZnO}: \mathrm{Al} / \mathrm{CdS} \\
/ \mathrm{HgCdTe}\end{array}$ & .960 & 2 & 62 & 1.2 & \\
\hline
\end{tabular}

Table 4. Tandem Structures and their Operating Parameters.

The NREL Polycrystalline Thin-Film Group recently demonstrated a 4-terminal polycrystalline thin-film tandem cell consisting of a CdTe-based top cell and a CIS-based bottom cell, officially measured at NREL with efficiency of $15.3 \%$. The top CdTe-based cell structure is: Corning glass/Cd-stannate/Zn-stannate/CdS:O/CdTe/CuxTe/ITO. The transparency of this structure is about $50 \%$. The device parameter of this cell measured at: $\mathrm{V}_{\text {oc }}=0.786$ volts, $J_{\mathrm{sc}}=25.55 \mathrm{ma} / \mathrm{cm}^{2}, \mathrm{FF}=68.9$, efficiency $=13.8 \%$. The CIS bottom cell structure is: glass $/ \mathrm{Mo} / \mathrm{CIS} / \mathrm{CdS} / \mathrm{ZnO}$. Its efficiency as measured under the transparent CdTe cell is $1.5 \%$. The performance of the CIS cell degraded somewhat during the processing of the stacks into a measurable structure. This achievement represents a benchmark and a first step for this device; work is ongoing to design material improvements and develop a more optimal structure.

\section{CONCLUSIONS}

Both monolithic and mechanical tandems have been developed under the project; they are listed in Table 4. These devices used high-bandgap alloys based on I-III- $\mathrm{VI}_{2}$ and II-VI compounds. To date, the highest efficiency reported on a 4-terminal structure is $15.3 \%$; thin CdTe is used for the high-bandgap top cell.

The developments under the High-Performance PV Project reported here are progress toward achieving longterm DOE-goals [1]. The project is focused to assure that tandem thin-film polycrystalline modules reach efficiency levels consistent with cost-competitive goals.

\section{ACKNOWLEDGMENTS}

This work is supported under DOE Contract No. DEAC36-99G010337 with NREL. Many people have contributed to the development and implementation of the High-Performance PV project and to the R\&D efforts carried out in this program.

The author thanks the NREL High-Performance Polycrystalline Thin-Film Tandem Group: Rommel Noufi, Tim Coutts, Anna Duda, David Young, Tim Gessert, Scott Ward, Miguel Contreras, Xianzhu Wu, Dave Albin, Ramesh Dhere, Kannan Ramanathan, Fallah Hasoon, Jehad Abushami, Dean Levi, Sally Asher, Manuel Romero, and Yanfa Yan. The author also thanks all HighPerformance PV subcontractors listed in Table 1.

\section{REFERENCES}

[1] U.S. Photovoltaic Industry Roadmap, Chicago, Illinois, Facilitated by the NCPV for the U.S. PV Industry, Prepared by Energetics, Incorporated (Columbia, Maryland), May, 2001, $32 \quad$ pp., $\quad$ URL: www.nrel.gov/ncpv/pdfs/30150/pdf

[2] E.D. Jackson, Rand Conf, Use of Solar Energy, p. 122. Tuscon, Arizona (1955).

[3] T. J. Coutts, S. Ward, D. Young, K. Emery, T. Gessert, and R. Noufi, Progress in Photovoltaics Research and Applications, 2003; 11-359-375.

[4] D. L. Young, M. Contreras, M. Romero, S. Asher, C. Perkins, T. Gessert,J. Keane, T. Coutts, R. Noufi, International PVSEC-14, Bangkok, Thailand, 2004. 


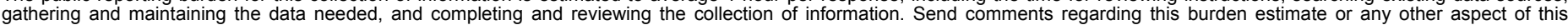

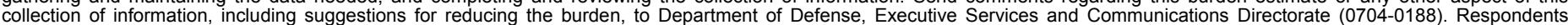

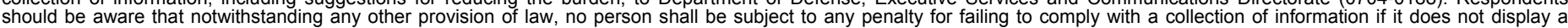

should be aware that notwithstanding

PLEASE DO NOT RETURN YOUR FORM TO THE ABOVE ORGANIZATION.

February 2005

Conference Paper

4. TITLE AND SUBTITLE

Status of High Performance PV: Polycrystalline Thin-Film Tandems 5a. CONTRACT NUMBER

DE-AC36-99-G010337

5b. GRANT NUMBER

5c. PROGRAM ELEMENT NUMBER

5d. PROJECT NUMBER

NREL/CP-520-37379

5e. TASK NUMBER

PVA50001

5f. WORK UNIT NUMBER
7. PERFORMING ORGANIZATION NAME(S) AND ADDRESS(ES)

National Renewable Energy Laboratory

1617 Cole Blvd.

Golden, CO 80401-3393
8. PERFORMING ORGANIZATION REPORT NUMBER

NREL/CP-520-37379

9. SPONSORING/MONITORING AGENCY NAME(S) AND ADDRESS(ES)

10. SPONSOR/MONITOR'S ACRONYM(S) NREL

11. SPONSORING/MONITORING AGENCY REPORT NUMBER

12. DISTRIBUTION AVAILABILITY STATEMENT

National Technical Information Service

U.S. Department of Commerce

5285 Port Royal Road

Springfield, VA 22161

13. SUPPLEMENTARY NOTES

\section{ABSTRACT (Maximum 200 Words)}

The High-Performance Photovoltaic (HiPerf PV) Project was initiated by the U.S. Department of Energy to substantially increase the viability of photovoltaics (PV) for cost-competitive applications so that PV can contribute significantly to our energy supply and our environment. The HiPerf PV Project aims at exploring the ultimate performance limits of existing PV technologies, approximately doubling their sunlight-to-electricity conversion efficiencies during its course. This work includes bringing thin-film cells and modules toward $25 \%$ and $20 \%$ efficiencies, respectively, and developing multijunction concentrator cells and modules able to convert more than one-third of the sun's energy to electricity (i.e., $33 \%$ efficiency). This paper will address recent accomplishments of the NREL in-house research effort involving polycrystalline thin-film tandems, as well as the research efforts under way in the subcontracted area.

\section{SUBJECT TERMS}

PV; high performance; conversion efficiency; thin film; solar cells; module; polycrystalline; tandems;

\begin{tabular}{|c|c|c|}
\hline 16. SECURIT & CLASSIFICATI & N OF: \\
\hline $\begin{array}{l}\text { a. REPORT } \\
\text { Unclassified }\end{array}$ & $\begin{array}{l}\text { b. ABSTRACT } \\
\text { Unclassified }\end{array}$ & $\begin{array}{l}\text { c. THIS PAGE } \\
\text { Unclassified }\end{array}$ \\
\hline
\end{tabular}

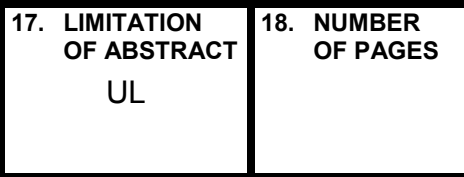

19a. NAME OF RESPONSIBLE PERSON

19b. TELEPHONE NUMBER (Include area code) 